\title{
Spinal compression of Atlantic cod Gadus morhua from the German Wadden Sea
}

\author{
Ingrid Hilger*
}

Institut für Meereskunde an der Universität, W-2300 Kiel 1, Germany

\begin{abstract}
A definition of spinal compression of Atlantic cod Gadus morhua L. from the German Wadden Sea is presented, based on the relation of head length to total body length of the fish. Compressed individuals are defined as having values of $x=H / T \times 100>27.74$ (where $H=$ head length and $T=$ total body length). Epizootiological results of an extensive field survey in 1989 revealed decreasing prevalence of compression with increasing fish length. In small cod of the Eider and Elbe estuaries, prevalence varied seasonally with a maximum in March-April, apparently due to abnormal migration behaviour of deformed fish. Prevalence was significantly higher in the northern part of the German Wadden Sea than in the estuaries of the Ems, Weser and Elbe.
\end{abstract}

\section{INTRODUCTION}

Various types of skeletal deformities have been described for a large variety of fish species (Dawson 1964, 1966, 1971, Dawson \& Heal 1976, Möller \& Anders 1986). In Atlantic cod Gadus morhua L., the conditions termed 'pughead' and spinal compression have been described as those most commonly occurring (Smith 1867, Lundbeck 1928, Schräder 1931, Marquard 1936, Wunder 1971\}. Recent quantitative data from the North Sea and Baltic Sea have been compiled by Möller (1981, 1983, 1984a). Between 1981 and 1986 about 200000 fish from the Elbe River were investigated for diseases, including skeletal deformities (Möller 1984b, 1988a, Pohl 1990).

Although a variety of causative factors can be demonstrated experimentally (Battle 1929, Gabriel 1944, Bengtsson 1975, Weis \& Weis 1976, Couch et al. 1977, 1979, Lodi 1978, Ozoh 1979, Bahrs 1981), the cause of spinal malformations in the wild usually remains unknown. An unsolved problem has been the reliable identification of spinal malformation. Reliable diagnostic methods, such as X-ray analysis or preparation of the spinal column, are difficult to apply during field investigations and are not suitable for routine

\footnotetext{
- Present address: Uni-Klinikum Göttingen, Zentrum Innere Medizin, Abt. Klinische Biochemie, Robert-Koch-Straße 40, W-3400 Göttingen, Germany
}

investigations involving large numbers of fish. Thus, on most previous surveys, malformations have been diagnosed by naked eye. It is possible that this subjective method of identification is inconsistent and does not allow quantification.

In this study, regional and seasonal fluctuations in the prevalence of spinal compression in Atlantic cod from the German Wadden Sea were examined, as part of a larger set of investigations on disease conditions of Atlantic cod in this area (Hilger 1990). An objective method for identifying spinal malformation is given, based on an analysis of the ratio of head length to total length of the fish examined. It is generally assumed that the anatomy of the head is not influenced by the factors which lead to spinal compression.

\section{MATERIALS AND METHODS}

Sampling. The cod used in this study were caught in the German Wadden Sea between January 1988 and December 1989 using commercial shrimp trawlers. Monthly samples were taken in the Eider and Elbe estuaries, whereas other stations were surveyed every 3 mo (Fig. 1). In 1989, a total of 10801 cod varying in total length from 7 to $46 \mathrm{~cm}$ were examined on board ship by the same investigator. Immediately after capture, fish were classified as 'normal' or 'compressed' by naked eye. Measurements of fish total body length 


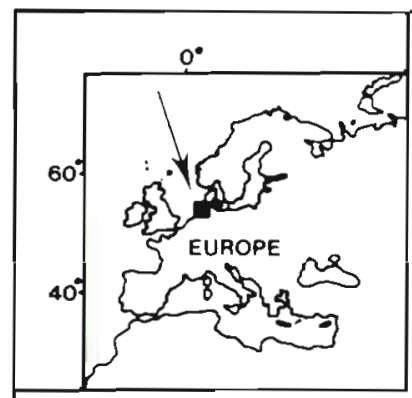

NORTH SEA
94

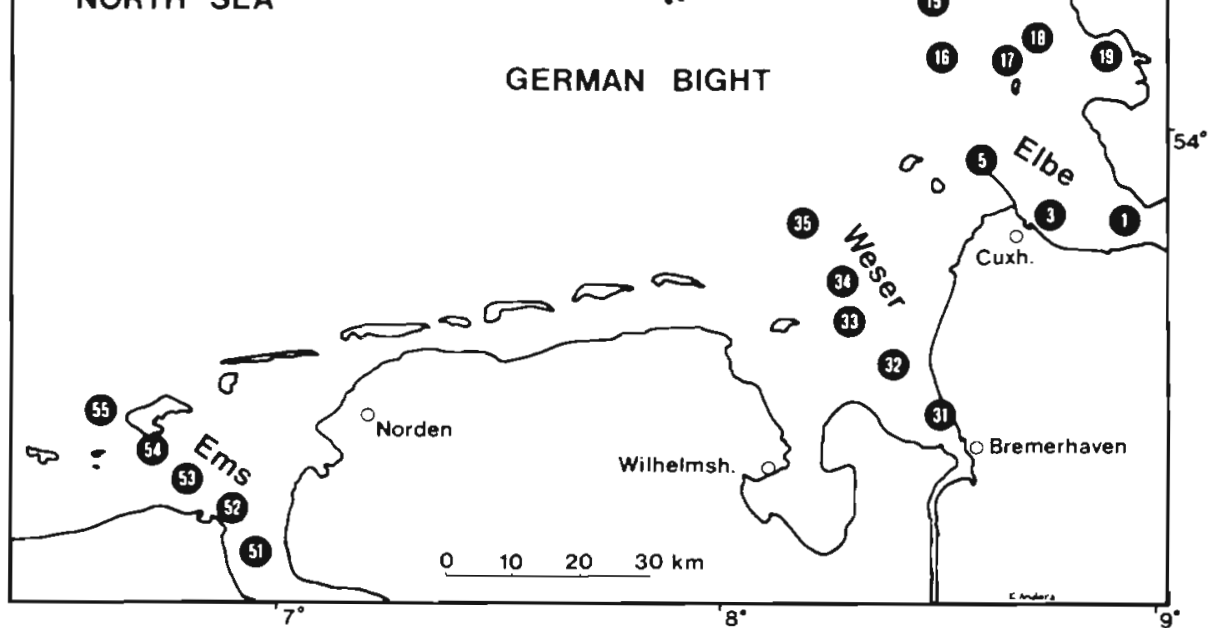

Fig. 1. Sampling area and locations in the German Wadden Sea were recorded to the nearest centimetre. From March to May 1988, September 1988 and January to May 1989, up to 50 individuals per haul were taken at random and stored frozen for further examination in the laboratory.

In the laboratory, measurements of total body length and head length (length between the tip of the mouth and the distal edge of the operculum) were recorded to the nearest millimetre. Altogether, 2995 specimens were examined.

Statistical analysis. For each fish examined the factor $x=H / T \times 100$ (where $H=$ head length and $T=$ total length) was calculated and the corresponding frequency distribution was determined (see Fig. 2). This distribution was separated into 2 Gaussian components using the method of Bhattacharya (1967), which is commonly applied in the separation of age groups in populations.

\section{RESULTS}

\section{Definition of spinal compression in cod}

The frequency distribution showed a peak at a compression factor of 25.25 (Fig. 2). Another component can be distinguished on the right side of Fig. 2, partly overlapping the main modal group. This is clearly not a simple Gaussian distribution.

Resolving the frequency distribution of $x$ in Fig, 2 into Gaussian components yields a separation index (SI) $=3.59$. This indicates that a resolution of the above-mentioned distribution is sensible (SI should be $\geq 2$ for groups to be meaningfully separated). The resultant components are Curves 1 and 2 , shown in Fig. 3. With a crossing point of $x=27.97 \%$ and $y=42.5$, the calculated overlapping areas are S1 $1.1 \%$ of Component 1$)$ and S2 (22.4\% of Component 2)

Values of $x$ from cod with spinal compression are higher than those of normal fish. Therefore, it can be concluded that Component 1 corresponds to the distribution of $x$ from healthy and Component 2 to compressed cod (Fig. 3). By plotting the factor $x$ from normal cod on the one hand and that of compressed individuals on the other, a distribution similar to that in Fig. 3 was obtained (data not shown).

To further analyze the variation in prevalence of 'this condition, a limiting value of $x$ can be defined which separates normal from compressed fish, so that normal and compressed individuals are equal in number. This value occurs where the area beneath the 2 overlapping curves in Fig. 3 is equal, i.e. at $x=27.74 \%$. Thus, normal individuals are characterized by values of 
Fig. 2. Gadus morhua. Relation of head length to total body length in $2995 \mathrm{cod}(8$ to $45 \mathrm{~cm}$ ) from the German Wadden Sea, March to May 1988, September 1988, and January to May 1989

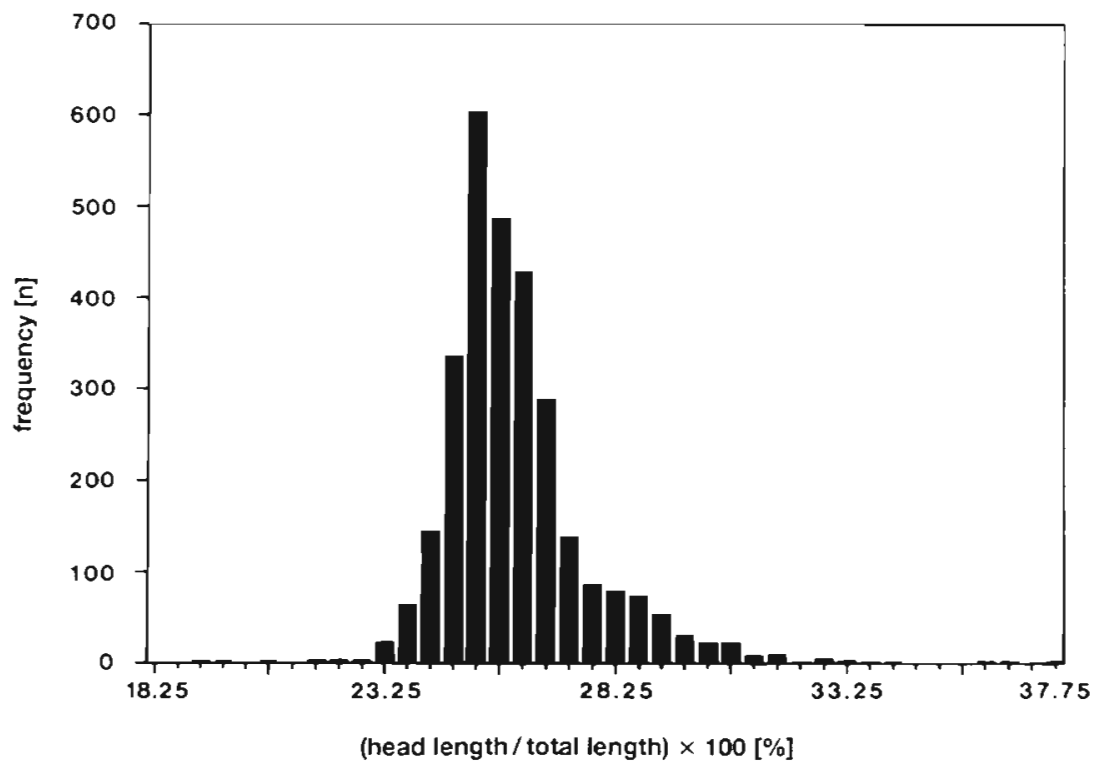

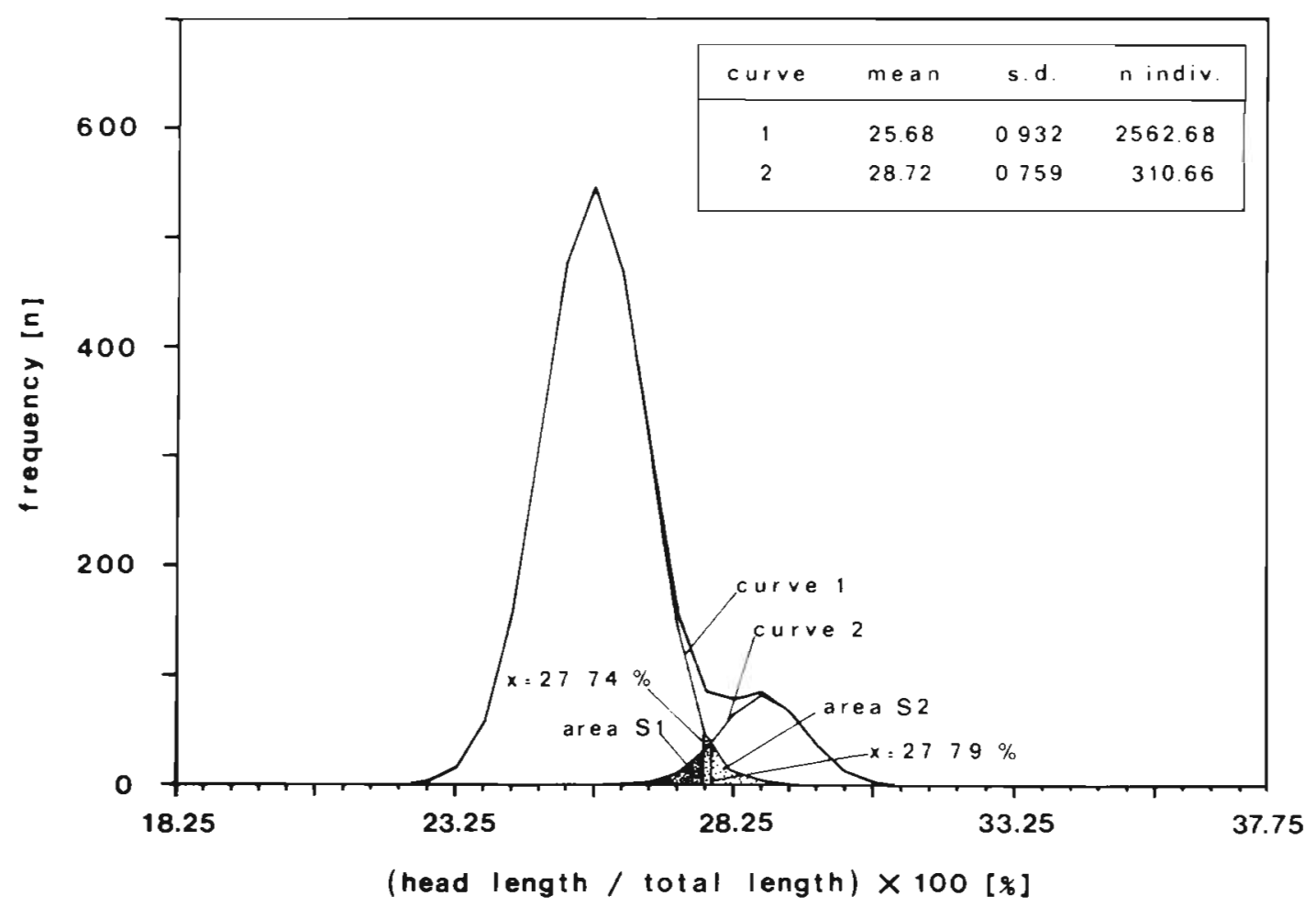

Fig. 3. Gadus morhua. Curve analysis according to the method of Bhattacharya (1967), based on data in Fig. 2

$x<27.74 \%$ and compressed ones by values of $x>$ $27.74 \%$.

After determining the proportion of compressed fish in a certain area and period of investigation, the corresponding percentage of compressed fish may be estimated. Based on the present limiting value, $9.2 \%$ of the young cod (11 to $23 \mathrm{~cm}$ ) from the German Wadden Sea showed spinal compression.

\section{Epizootiological results}

Of all young cod examined by eye on board ship, $4.9 \%$ were found to have spinal compression $(2.2 \%$ in 1988 and $7.1 \%$ in 1989). Deformed fish were found in almost all $\mathrm{cm}$ groups. However, prevalence decreased with increasing fish length (Fig. 4).

In the estuaries of the Elbe and Eider, where most 


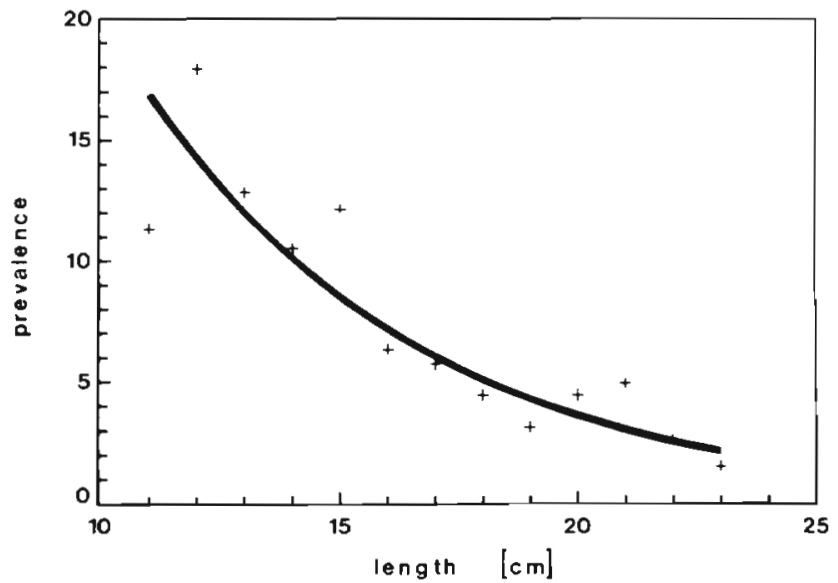

Fig. 4. Gadus morhua. Observed (crude) prevalence (\%) of young cod with spinal compression vs total fish length, January to August 1989, Elbe and Eider estuaries. Regression curve: $Y=e^{a+b x}$, where $a$ and $b$ are constants; correlation coefficient $r=-0.93$

samples had been taken, a clear seasonal cycle in the occurrence of the disease could be demonstrated: the prevalence increased from an average of $3.9 \%$ between January and April to $27.3 \%$ in May in the Elbe estuary, and from an average of $3.3 \%$ between January and March to $26.9 \%$ in April in the Eider estuary (Table 1).

Table 1. Gadus morhua. Seasonal differences in observed prevalence $(\%)$ of young cod $(11$ to $23 \mathrm{~cm})$ with spinal compression, from the Elbe and Eider estuaries in 1989. Data adjusted to the $17 \mathrm{~cm}$ group, in accordance with Möller (1983). $\mathrm{n}$ : no. examined

\begin{tabular}{|lrccc|}
\hline \multirow{2}{*}{ Month } & \multicolumn{2}{c}{ Elbe estuary } & \multicolumn{2}{c|}{ Eider estuary } \\
& n & Prevalence & $\mathrm{n}$ & Prevalence \\
\hline Jan & 188 & 1.0 & 698 & 0.9 \\
Feb & 132 & 2.9 & 192 & 0.8 \\
Mar & 128 & 2.3 & 967 & 8.3 \\
Apr & 112 & 9.5 & 186 & 26.9 \\
May & 20 & 27.3 & 0 & - \\
Jun & 0 & - & 0 & - \\
Jul & 0 & - & 0 & - \\
Aug & 2 & 0.0 & 0 & - \\
Sep & 25 & 0.0 & 2 & 0.0 \\
Oct & 19 & 0.0 & 88 & 4.2 \\
Nov & 18 & 5.5 & 38 & 10.5 \\
Dec & 61 & 11.0 & 148 & 0.0 \\
& & & & \\
\hline
\end{tabular}

Regarding regional differences in disease prevalence, relatively low values were found for cod from estuaries of the Ems, Weser and Elbe (1.4, 0.5 and $2.3 \%$ respectively). Along the coast of the Wadden Sea, prevalences were comparatively high $(13.5 \%$ in the Süderpiep and $11.7 \%$ in the Süderaue) (Table 2).
Table 2. Gadus morhua. Regional differences in the observed prevalence $(\%)$ of spinal compression in young cod (11 to 23 $\mathrm{cm})$ from the German Wadden Sea. Data from March 1989. Data adjusted to the $17 \mathrm{~cm}$ group, in accordance with Moller (1983). n: no. examined. See Fig. 1 for station locations

\begin{tabular}{|lccc|}
\hline Region & Station & $\mathrm{n}$ & Prevalence \\
\hline Ems estuary & $51-55$ & 70 & 1.4 \\
Weser estuary & $31-35$ & 99 & 0.5 \\
Elbe estuary & $1-5$ & 128 & 2.3 \\
Süderpiep & $16-19$ & 496 & 13.5 \\
Eider estuary & $11-14$ & 967 & 8.3 \\
Hever stream & $41-45$ & 663 & 7.5 \\
Süderaue stream & $61-64$ & 506 & 11.7 \\
\hline
\end{tabular}

\section{DISCUSSION}

It is assumed that our present knowledge on the occurrence of spinal compression in wild populations is based on rather subjective data. From the data pool in Figs. $2 \& 3$ for cod from the Wadden Sea, it is evident that compressed fish cannot be identified properly by naked eye. Furthermore, it is assumed that results from different investigators are largely influenced by differences in the identification success of the individual researcher, thus making comparison difficult (Möller $1988 \mathrm{~b})$. The need for a standardized diagnostic method is evident. The application of a proper double measurement ( $H$ and $T$ ) during this study revealed a prevalence of $9.2 \%$, while the usual field observation technique revealed a value of only $4.9 \%$.

Morphometric measurements lead to more precise and consistent results than estimations or other semiquantitative methods. By relating head length to total length, it is possible to determine 2 different types of frequency distribution: (1) In the case where similar numbers of normal and compressed individuals are present, curves as shown in Fig. 5 are obtained, suggesting a clear demarcation of the 2 groups. That means that there is a certain time in the life of individual fish when one or several factors determine whether they will grow normally or not. (2) The curves illustrated in Fig. 3 suggest the existence of 2 normally distributed components partially overlapping each other. If this assumption is confirmed, it means that a fish is either healthy or compressed. Consequently, the overlapping of the 2 curves is due to a variability in growth of both groups and to the fact that generally many more normal than compressed fish are present. For a clear separation of normal and compressed fish, a limiting value of $x=27.74 \%$ was proposed in the present study. It is not known if this finding can be applied to other cod or other fish populations.

Several fish diseases such as bacterial infections of 


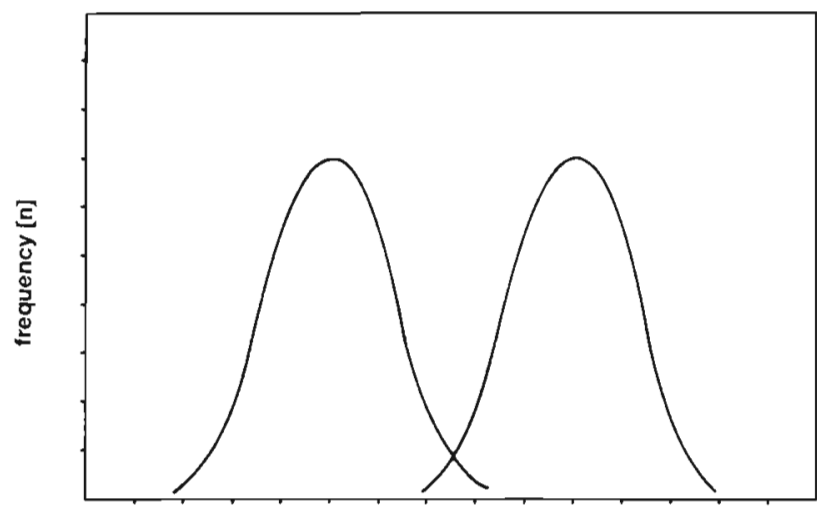

(head length / total length) $\times 100[\%]$

Fig. 5. Gadus morhua. Theoretical relation of head length to total body length given a similar number of normal and compressed fish

flounder have been recorded most frequently in the estuaries of the Elbe, Eider and Weser, although papillomatosis of smelt and dab occurred most frequently in the northernmost area of the Wadden Sea (Möller 1990, Anders \& Möller 1991, Hilger et al. 1991). In contrast to these diseases, spinal compression of cod was found to be most prevalent along the open coast of the Wadden Sea outside the estuaries, which are considered to offer the most stressful anthropogenic and natural conditions for fish. It must be considered, however, that most kinds of skeletal anomalies in fish are supposedly acquired during embryonic and larval stages (Möller \& Anders 1986). An accumulation of adult or even juvenile deformed fish in a certain area thus does not necessarily mean that the cause of the disorder can be found in that area.

The seasonal variations in prevalence of compression found during this study coincide with temporarily high prevalences of spinal compression in cod reported by Wunder (1971) and Möller (1983) from the Elbe estuary. Moller's finding of clear seasonal fluctuations in prevalence seems to be valid for the whole area under investigation. Normally, cod of age-group 0 invade the shallow waters of the Wadden Sea in autumn. They leave this area again before the next age group arrives in spring of the following year (Lamp 1973). It is assumed that, in contrast to normal cod, compressed fish remain for a longer time, in coastal waters leading to relatively high prevalences (Möller \& Anders 1986) in April and May (Table 1).

The data shown in Fig. 4 suggest that spinal compression may have a negative selection effect on young fish, e.g. lead to higher predation on diseased fish. In order to validate this suggestion, it would be useful to plot the prevalence data against head length, a variable which is presumed not to be influenced by the condition. In the present study, these data were not available for every fish examined on board ship, since the examination was carried out within a routine framework of a field survey

The cause of the condition remains unknown. The locally and seasonally high prevalence of this disease in cod, and even higher prevalences of skeletal anomalies in young smelt from the lower Elbe River (Pohl 1990), justify further investigations.

Acknowledgements. I express my appreciation to PD Dr $\mathrm{H}$. Möller and Prof. Dr D. Schnack for helpful suggestions. I also thank. Dr K. Anders for critical comments and Drs M. Prein and J. M. Vakily for their help during statistical analysis. This research was carried out as part of a field survey on fish diseases in the German Wadden Sea in 1988/1989, financed by the Governments of Schleswig-Holstein and Lower Saxony and the German Federal Environmental Agency.

\section{LITERATURE CITED}

Anders, K., Möller, H. (1991). Epidemiologische Untersuchungen an Fischen des Wattenmeeres. Ber. Inst Meeresk. Kiel 207, $166 \mathrm{p}$

Bahrs, P. (1981). Wirkung verschiedener Fungizide auf die Entwicklung von Fischeiern. Diplom thesis. University of Kie!

Battle, H. I. (1929). Effects of extreme temperatures and salinities on the development of Enchelyopus cimbrius (L.) Contr Can. Biol. Fish. 5: 107-192

Bengtsson, B.-E. (1975). Vertebral damage in fish induced by pollutants. In: Koeman, J. H., Strik, J. J. W. A. (eds.) Sublethal effects of toxic animals. Elsevier, Amsterdam, p. 23-30

Bhattacharya, C. G. (1967). A simple method of resolution of a distribution into Gaussian components. Biometrics 23: $115-135$

Couch, J. A., Winstead, J. T., Goodman, L. R. (1977). Keponeinduced scoliosis and its histological consequences in fish Science 197: 585-587

Couch, J. A., Winstead, J. T., Hansen, D. J., Goodman, L. R. (1979). Vertebral dysplasia in young fish exposed to the herbicide trifluralin. J. Fish Dis. 2: 35-42

Dawson, C. E. (1964). A bibliography of anomalies of fishes. Gulf Res. Rep. 1: 308-319

Dawson, C. E. (1966). A bibliography of anomalies of fishes. Supplement 1. Gulf Res. Rep. 2: 169-176

Dawson, C. E. (1971). A bibliography of anomalies of fishes. Supplement 2. Gulf Res. Rep. 3: 215-239

Dawson, C. E., Heal, E. (1976). A bibliography of anomalies of fishes. Supplement 3. Gulf Res. Rep. 5: 35-41

Gabriel, M. L. (1944). Factors affecting the number and form of vertebrae in Fundulus heteroclitus. J. exp. Zool. 95: 105-147

Hilger, I. (1990). Kondition und Gesundheitszustand des Dorsches im Wattenmeer 1988-1989. Diplom thesis. University of Kiel

Hilger, I, Ullrich, S., Anders, K. (1991). A new ulcerative flexibacteriosis-like disease ('yellow pest') affecting young Atlantic cod Gadus morhua from the German Wadden Sea. Dis. aquat. Org. 11. 19-29

Lamp, F. (1973). Das Wanderverhalten des Kabeljaus der Deutschen Bucht. Arch. FischWiss. 24(1-3): 155-169 
Lodi, E. (1978). Palla: a hereditary vertebral deformity in the guppy (Poecilla reticulata Peters (Pisces, Osteichthys)). Genetica 48: 197-200

Lundbeck, J. (1928). Beobachtungen über Mißbildungen und Erkrankung von Dorschen an der ostpreußischen Küste. $Z$. Fisch. 26: 457-472

Marquard, D. (1936). Kopfmißbildungen an Dorschen der Ostsee. Z. Fisch. 34: 249-256

Mölier, H. (1981). Fish diseases in German and Danish coastal waters in summer 1980. Meeresforsch. 29: 1-16

Möller, H. (1983). High skeletal deformation rates of cod in the Elbe estuary. Bull. Eur Ass. Fish Pathol. 3: 7-8

Möller, H. (1984a). Dynamics of fish diseases in the lower Elbe River. Helgoländer Meeresunters. 37: 389-413

Möller, H. (1984b). Daten zur Biologie der Elbfische. Möller, Kiel

Möller, H. (1988a). Fischbestände und Fischkrankheiten in der Unterelbe 1984-1986. Moller, Kiel

Möller, H. (1988b). The problem of quantifying long-term changes in the prevalence of tumors and non-specific growths of fish. J. Cons. int. Explor. Mer 45: 33-38

Möller, H. (1990). Association between diseases of flounder (Platichthys flesus) and environmental conditions in the Elbe estuary, FRG. J. Cons. int Explor. Mer 46: 187-199

Responsible Subject Editor: O. Kinne, Oldendorf/Luhe, Germany
Móller, H., Anders, K. (1986). Diseases and parasites of marine fishes. Möller, Kiel

Ozoh, P. T (1979). Malformations and inhibitory tendencies induced to Brachydanio rerio (Hamilton-Buchanan) eggs and larvae due to exposures in low concentrations of lead and copper ions. Bull. envir. Contam. Toxicol. 21: 302-303

Pohl, C. (1990). Skeletal deformities and trace metal contents of European smelt, Osmerus eperlanus, in the Elbe estuary. Meeresforsch. 33: 76-89

Schräder, T. (1931). Mißbildungen der WirbeIsäule bei Fischen. Mitt. Fischereivereine Prov. Brandenburg, Ostpreußen 23: 527-529

Smith, J. A. (1867). Notice of various specimens of the deformed variety of Morrhua vulgaris, the common codfish - the 'Lord Fish' of Yarrel - recently taken in the Firth of Forth. Proc. R. phys. Soc. Edinb. 3: 302-303

Weis, P., Weis, J. S. (1976). Abnormal locomotion associated with skeletal malformations in the sheepshead minnow, Cyprinodon variegatus, exposed to malathion. Envir. Res. 12: $196-200$

Wunder, W. (1971). Mißbildungen beim Kabeljau (Gadus morhua) verursacht durch Wirbelsäulenverkürzung. Helgoländer Meeresunters. 22: 201-212

Manuscript first received: October 1, 1991

Revised version accepted: April 30, 1992 